\title{
Peranan Kantor Perwakilan Bank Indonesia Provinsi Sulawesi Tengah Dalam Upaya Meningkatkan Penggunaan Uang Logam
}

\author{
Sahrul Gunawan ${ }^{1 *}$, Malkan Malkan ${ }^{2}$, Abdul Jalil ${ }^{3}$ \\ ${ }^{1}$ Jurusan Perbankan, Fakultas Ekonomi dan Bisnis Islam, IAIN Palu \\ ${ }^{2}$ Jurusan Perbankan, Fakultas Ekonomi dan Bisnis Islam, IAIN Palu \\ ${ }^{3}$ Jurusan Perbankan, Fakultas Ekonomi dan Bisnis Islam, IAIN Palu
}

\section{ABSTRAK}

Uang dalam ilmu ekonomi tradisional didefinisikan sebagai alat tukar yang dapat diterima secara umum. Alat tukar itu dapat berupa benda apapun yang dapat diterima oleh setiap orang di masyarakat dalam proses pertukaran barang dan jasa. Uang pada umumnya terdiri dari uang kertas dan uang logam. Uang merupakan alat transaksi yang sah yang dikeluarkan oleh pemerintah Republik Indonesia dalam hal ini Bank Indonesia sebagai Bank sentral yang sangat berperan dalam mendistribusikan, manrik, dan memusnakan uang sebagaimana yang telah diamantkan oleh Undang-undang. Penelitian ini menggunakan metode penelitian Kualitatif, dengan menggunakan metode observasi, wawancara dan dokumentasi. Dalam penelitian penulis menerangkan dimana peran Bank Indonesia dalam menjaga kelancaran sistem pembayaran yang ada di masyarakat, penggunaan trend uang logam sebagai alat pembayaran sangat memperihatinkan khususnya di Kota Palu. Dalam Undang-Undang Nomor 7 Tahun 2011 menjalaskan secara terprinci sanksi tehadap penolakan uang logam sebagai alat pembayaran. Hasil penelitian ini menjelaskan Peranan Kantor Perwakilan Bank Indonesia Provinsi Sulawesi Tengah dalam 1. Upaya meningkatkan penggunaan uang logam di masyarakat kurang maksimal. 2. Karena beberapa kendala yang dihadapi mulai dari letak geografis dan Sumber Daya Manusia (SDM). Saran penulis dari penelitian ini adalah Kantor perwakilan Bank Indonesia Provinsi Sulawesi Tengah harus memaksimalkan perannya sebagai Bank Sentral yang berada di daerah yang harus menjaga dan melancarkan sistem pembayaran dengan menggunakan uang logam.

\section{INFORMASI \\ ARTIKEL}

Katakunci:

Bank Indonesia Uang

Logam

Peran BI

Sulawesi Tengah 


\section{PENDAHULUAN}

Dinamika kehidupan masyarakat dewasa ini, telah melahirkan pola pemikiran baru yang turut berkembang seiring dengan kemajuan zaman. Ketika mekanisme pembayaran dituntut untuk selalu mengakomodir setiap kebutuhan masyarakat dalam hal perpindahan dana secara cepat, aman dan efisien, maka inovasi-inovasi teknologi pembayaran semakin bermunculan dengan sangat pesat. Memberikan jawaban dengan berbagai fasilitas kemudahan dan semakin tiada batas. Bank Indonesia dituntut untuk selalu memastikan bahwa setiap perkembangan system pembayaran harus selalu berada pada koridor ketentuan yang berlaku. Hal ini tentu saja demi kelancaran dan keamanan jalannya kegiatan system pembayaran.

Uang adalah alat tukar yang dapat diterima secara umum, suatu yang tersedia dan secara umum oleh masyarakat untuk mengukur nilai, menukar, dan melakukan pembayaran atas pembelian barang dan jasa dan pada waktu yang bersamaan bertindak sebagai alat penimbun kekayaan. ${ }^{1}$ Pada awalnya manusia memenuhi kebutuhannya secara mandiri. Mereka memenuhi kebutuhannya dengan cara memanfaatkan apa yang mereka peroleh dari alam karena pada saat itu kebutuhan manusia masih

\footnotetext{
${ }^{1}$ http://id.m.wikiedia.org/woki/uang diakses 1Agustus 2017
}

sangat sederhana. Ketika jumlah manusia semakin bertambah dan peradabannya semakin maju, kegiatan dan interaksi antar sesama manusia pun meningkat tajam menyebabkan jumlah dan jenis kebutuhan manusia juga semakin beragam. ${ }^{2}$

Uang mulai digunakan di Indonesia pada saat situasi perekonomian sudah sedemikian berkembang, sebelum uang mulai digunakan Barter merupakan cara manusia untuk memperoleh kebutuhan. Barter yaitu pertukaran suatu barang/komoditi dengan komoditi lain secara langsung sesuai dengan kebutuhan yang bersangkutan. ${ }^{3}$ Uang kemudian berkembang dan berevolusi mengikuti perjalanan sejarah. Dari perkembangan inilah uang kemudian dapat dikategorikan dalam tiga jenis yaitu uang barang, uang kertas dan uang giral. ${ }^{4}$

Pecahan uang yang pernahdikeluarkan Pemerintah Republik Indonesia dalam melancarkan transaksi di masyarakat antara lain lima satuan uang kertas masing-masing bernilai Rp. 100,-,Rp. 500,- , Rp. 1.000,-, Rp. 5.000,-, Rp. 10.000,- Masing-masing uang kertas dihias dengan warna-warna cerah dengan gambar-gambar menarik

\footnotetext{
${ }^{2}$ Mustafa Edwin Nasution, et al. eds. Pengenalan Eksklusif Ekonomi Islam (Jakarta: Prenada Media Group, 2006), hlm. 239.

${ }^{3}$ Sri Mulyani Indrawati,. Teori Moneter, Lembaga penerbit Fakultas Ekonomi Universitas Indonesia. Jakarta : 1988. h.4
}

${ }^{4}$ Ibid; h.240 
kecuali uang logam dan pecahan uang logam yang ada adalah satu rupiah, lima rupiah, sepuluh rupiah, dua puluh lima rupiah, lima puluh rupiah dan seratus rupiah. ${ }^{5}$

Semakin kecilnya nilai nominal mata uang rupiah, hal itu berdampak pada semakin sedikitnya jumlah uang koin yang beredar di masyarakat. Memang disini tidak sedang membahas masalah keekonomian uang pecahan koin, namun lebih menyoroti peranan masyarakat dalam menggunakan uang koin.

Kelancaran sistem pemayaran Nasional dibutuhkan Lembaga ataupun Istitusi dalam menendalikan dan mengatur jumlah uang yang beredar. Menajaga stabilitas nilai tukar rupiah adalah tujuan Bank Indonesia yang diamanatkan dalamUndamg-Undang Nomor 23 tahun 1999 tentang Bank Indonesia, untuk menjaga stabilitas rupiah perlu disokong pengaturan dan pengelolahan akan kelancaran system pembayaran Nasional. Bank Sentral atau dalam hal ini Bank Indonesia juga adalah satu-satunya lembaga yang berhak mengeluarkan dan mengedarkan alat pembayaran tunai seperti rupiah. Bank Indonesia juga berhak mencabut, menarik dan memusnakan uang rupiah yang sudah tak berlaku dari peredaran dan kewenangan

\footnotetext{
${ }^{5}$ Tim Alumni,. Koleksi Mata Uang Berbagai Negara., penerbit alumni 1985 bandung. Bandung:1985. h. 5,6
}

tersebut diperkuat dalam Undang-Undang Nomor 7 Tahun 2011 Tentang Mata Uang.

Banyaknya Uang Logam yang telah dikeluarkan oleh Bank Indonesia.

"Bahwa Uang Koin alat pembayaran yang sah di Republik Indonesia namun umumnya uang koin ini tidak beredar di Masyarakat. Bank Indonesia telah mengeluarkan uang koin sekitar Rp 6 Triliun, namun yang kembali di Bank Indonesia hanya Rp 900 Milyar atau 6\% dengan tren semakin menurun". 6

Berbagai realita yang dilakukan beberapa masyarakat bahkan sudah tidak lagi menerima beberapa nominal uang logam, ketidaktahuan masyarakat dalam menggunakan uang logam menjadi alasan kenapa uang logam ditolak keberadaannya oleh masyarakat. Uang logam dikategorikan masih berlaku apabila belum ada pemgumuman oleh Bank Indonesia sebagai pihak yang bertanggung jawab bahwa uang tersebut telah ditarik peredaranya berdasarkan Tahun keluaran uang tersebut.

Dalam perkembangannya uang koin menimbulkan permasalahan dalam pelaksanaan sistem pembayaran, khususnya untuk transaksi yang berjumlah besar. Melihat fenomena sekarang, keadaan uang yang beredar di masyarakat cukup memprihatinkan terutama uang logam. Kepedulian masyarakat terhadap keberadaan uang logam kurang. Mereka lebih sering

\footnotetext{
${ }^{6}$ Departemen Komunikasi Bank Indonesia, 25 Juni 2016http://bi.go.id
} 
menggunakan uang kertas untuk bertransaksi dan cenderung menyimpan uang logam di rumah dan tidak menggunakannya untuk melakukan transaksi pembayaran. Hal ini mengakibatkan uang logam tidak berputar sebagai alat transaksi pembayaran, sehingga uang logam yang dikeluarkan oleh Bank Indonesia tidak pernah kembali ke sistem perbankan. Pada akhirnya Bank Indonesia akan terus meningkatkan kebutuhan percetakan uang logam pada hal biaya percetakan uang logam jauh lebih mahal dibandingkan dengan percetakan uang kertas namun tidak dimanfaatkan secara optimal.

Berdasarkan uraian di atas, maka penulis tertarik untuk meneliti lebih jauh mengenai bagaimana transaksi uang koin di masyarakat, dalam memaksimalkan peredaran uang koin sebagai alat pembayaran yang sah dalam negeri, minimnya masyarakat menggunakan uang logam sebagai alat pembayaran sangat tidak wajar penolakan sering saja terjadi apabila pemayaran taransaksi dengan menggunakan uang koin.

\section{TINJAUAN PUSTAKA}

\subsection{Penelitian Terdahulu}

Penelitian yang dilakukan Sindi Cahya Yuniar Mahasiswa Universitas Pembangunan Nasional "Veteran" Jawa Timur, Mahasiswa Fakultas Ilmu Sosial dan
Ilmu Politik Jurusan Ilmu Administrasi Bisnis yang berjudul "Kepuasan Konsumen Terhadap Pengembalian Uang Koin Yang Diganti Permen (Studi Kasus Minimarket Di Daerah Sekitar UPN "Veteran" Jatim) ". ${ }^{7}$ Penelitian Ini bertujuan untuk mengetahui kepuasan konsumen terhadap uang kembalian menggunakan permen. Hasil penelitian ini ternyata sangat meresahkan masyarakat dikarenakan kembalian uang diganti dengan permen, hubungan penelitian ini dan penelitian yang dilakukan oleh penulis saling berkaitan dikarenakan penelitian sebelumnya meneliti bagaimana kepuasan masyarakat terhadap uang kembalian digantikan dengan permen, sedangakan penulis meneliti bagaimana upaya Bank Indonesia Kantor Perwakilan Sulawesi Tengah dalam meningkatkan penggunaan uang logam dan penelitian ini menggunakan penelitian lapangan yang turun langsung ke lapangan untuk memperoleh data yang diperlukan melalui wawancara kepada informan ataupun dokumen.

$$
\text { Penelitian yang dilakukan Rizki }
$$
KamaliaTahun 2017 Mahasiswa Institut Agama Islam Negeri Antasari (IAIN Antasari) Kalimantan Selatan. Mahasiswa Fakultas Syariah dan Ekonomi Islam Jurusan

\footnotetext{
${ }^{7}$ Rabiatul Adawiyah, "Peranan Kantor Perwakilan Bank Indonesia Kalimantan Selatan Dalam Upaya Meningkatkan Penggunaan Uang Logam” (Kalsel: Jurusan Perbankan Syariah, Skrpsi ini tidak diterbitkan 2017)
} 
Pebankan Syariah yang berjudul "Peranan Kantor Perwakilan Bank Indonesia Provinsi Kalimantan Selatan dalam Pemenuhan Uang Layak Edar". ${ }^{8}$ Penelitian ini bertujuan untuk mengetahui peranan Kantor Perwakilan Bank Indonesia Provinsi Kalimantan Selatan daam pemenuhan uang layak edar di masyarakat hubungan penelitian ini dengan penelitian yang dilakukan penulis saling brkaitan dikarenakan membahas mengenai peranan Bank Indonesia. Teknik pengumpulan data yang digunakan adalah dengan wawancara dan dokumenter dengan metode kualitatif.

Penelitian yang dilakukan oleh Ayu Alifiandri Zainal.Tahun 2015 dengan judul "Peran Bank Indonesia dalam MenganggulangiPeredaran Uang Palsu di Indonesia Berdasarkan Pasal 244 dan 245 KUHP". 9 Skripsi Program Studi Ilmu Hukum, Fakultas Hukum, Universitas Hasanuddin. Dalam penelitian tersebut meneliti tentang usaha apa yang telah dilakukan oleh Bank Indonesia dan

${ }^{8}$ Rizki Kamalia, Fakultas Syariah dan Ekonomi Islam Jurusan Perbankan Syariah, Peranan Kantor Perwakilan Bank Indonesia Provinsi Kalimantan Selatan dalam Pemenuhan Uang Layak Edar, Institut Agama Islam Negeri AntasariKalimantan Selatan, 2017

${ }^{9}$ Atu Alfiandri Zainal, Fakultas Hukum Jurusan Ilmu Hukum, Peran Bank Indonesia dalam MenganggulangiPeredaran Uang Palsu di Indonesia Berdasarkan Pasal 244 dan 245 KUHP, Universitas Hasanuddin, Makassar, 2015 hambatan yang di alami Bank Indonesia dalam menanggulangi peredaran uang palsu di Indonesia berdasarkan pasal 244 dan 254 KUHP. Metode penelitian yang digunakan dalam penelitian ini menggunakan teknik pengumpulan data dengan cara penelitian kepustakaan dan penelitian lapangan. Hasil penelitian menujukan bahwa Bank Indonesia telah melakukan usaha semaksimal mungkin dalam menanggulangi peredaran uang palsu berdasarkan pasal 244 dan 254 KUHP dengan cara preventif dan reventif. Sedangkan hambatan yang dialami Bank Indonesia dalam menanggulangi peredaran uang palsu di Indonesia adalah tingkat pemalsuan uang yang semakin canggih, sulitnya melakukan sosialisasi di daerahdaerah pelosok dan perbatasan NKRI dan keengganan Masyarakat untuk melaporkan Rupiah yang diragukan keasliannya. Persamaan dengan penelitian penulis adalah membahas tentang peranan Bank Indonesia. Namun perbedaan terdapat pada objek yang di teliti dimana penelitian ini meneliti penangulangan peredaran uang palsu di Indonesia sedangkan penelitian yang penulis angkat adalah upaya Kantor Perwakilan Bank Indonesia dalam memaksimalkan penggunaan uang logam di masyarakat.

\subsection{Wewenang Bank Indonesia}

Undang-Undang Nomor 23 Tahun 1999 yang telah diubah beberapa kali terakhir dengan Undang-Undang Nomor 6 
Tahun 2009 tentang Bank Indonesia (Undang-Undang Bank Indonesia) Pasal 4 bahwa Bank Indonesia adalah Bank Sentral Republik Indonesia. Lebih lanjut Pasal 7 UU tersebut menjelaskan bahwa tujuan Bank Indonesia adalah mencapai dan memelihara kestabilan nilai Rupiah.

Kestabilan nilai Rupiah itu terdiri atas dua aspek yaitu, ${ }^{10}$

a. Kestabilan terhadap barang dan jasa.

b. Kestabilan terhadap mata uang negara lain (kurs).

Kestabilan nilai Rupiah terhadap barang dan jasa tercermin pada perkembangan laju inflasi, sedangkan kestabilan nilai Rupiah terhadap mata uang negara lain tercermin pada perkembangan nilai tukar (kurs) Rupiah terhadap mata uang negara lain. Penetapan tujuan memelihara stabilitas nilai Rupiah memberikan batas tanggung jawab yang jelas bagi Bank Indonesia dalam melaksanakan tugasnya dan dalam menetapkan sasaran yang harus dicapai.

Berdasarkan tujauan Bank Indonesia dalam menjaga dan menstabilkan nilai rupiah dalam sebagaimana yang diamanatkan dalam Undang-Undang Pasal 7, maka Bank indonesia dalam hala ini kantor perwakilan Bank Indoneisa Sulawesi Tengah harus sangat aktif dalam menjaga kelancaran sistem pembayaran dan salah satunya adalah kelancaran dalam transaksi Uang Logam.

Untuk mewujudkan tujuan dalam mencapai dan memelihara kestabilan nilai Rupiah, Undang-Undang Bank Indonesia Pasal 8 menjelaskan bahwa Bank Indonesia mempunyai tiga tugas sebagai berikut: ${ }^{11}$

a. Menetapkan dan melaksanakan kebijakan moneter;

b. Mengatur dan menjaga kelancaran sistem pembayaran; dan

c. Mengatur dan mengawasi bank.

Tugas pertama adalah menetapkan dan melaksanakan kebijakan moneter. Tugas ini diarahkan dalam rangka mengendalikan jumlah uang yang beredar dan /atau suku bunga agar dapat mendukung pencapaian tujuan kestabilan nilai uang, sekaligus mendorong perekonomian nasional. Dalam melaksanakan tugas kebijakan moneter, bank sentral senantiasa memantau perkembangan dan kecenderungan berbagai variabel ekonomi makro, moneter, dan keuangan.Bank sentral juga senantiasa melakukan koordinasi dengan Pemerintah agar terjadi kerjasama yang padu antara kebijakan moneter dan kebijakan fiskal serta kebijakan ekonomi makro lainnya.Hasil analisis dan pemantauan digunakan oleh bank sentral dalam melaksanakan kebijakan moneternya.

${ }^{10}$ Bank Indonesia, Buku Panduan Guru Ekonomi SMA/MA muatan kebanksentralan 2014., h.60

${ }^{11}$ Ibid., h.62 
Tugas kedua adalah mengatur dan menjaga kelancaran sistem pembayaran, yang mencakup sekumpulan kesepakatan, aturan, standar, dan prosedur yang digunakan dalam mengatur pere daran uang.Sistem pembayaran dapat berlangsung, baik secara tunai maupun nontunai.Sistem pembayaran tunai menyangkut pencetakan dan pengedaran uang agar jumlah, denominasi, kelayakan, ataupun keamanan uang sebagai alat pembayaran yang sah dapat memenuhi kebutuhan masyarakat dalam melaksanakan berbagai aktivitas ekonomi. Adapun sistem pembayaran nontunai menyangkut peredaran uang yang pada umumnya dalam bentuk giral dan produk-produk perbankan lainnya, baik melalui proses kliring antarbank, kartu kredit, ataupun Anjungan Tunai Mandiri (ATM).

Tugas ketiga adalah mengatur dan mengawasi perbankan. Peran penting perbankan terutama terletak pada fungsinya sebagai lembaga kepercayaan dalam memobilisasi dana masyarakat dan menyalurkannya dalam bentuk kredit dan alternatif pembiayaan lainnya untuk dunia usaha. Perbankan mempunyai peran vital dalam pelaksanaan kebijakan moneter karena sebagian besar peredaran uang dalam perekonomian berlangsung melalui perbankan.
Adapun wewenang yang diberikan oleh Undang-Undang dalam rangka melaksanakan tiga tugas di atas adalah sebagai berikut. ${ }^{12}$

a. Wewenang terkait dengan tugas menetapkan dan mel aksanakan kebijakan moneter meliputi:

1) Menetapkan sasaran-sasaran moneter dengan memerhatikan sasaran laju inflasi,

2) Melakukan pengendalian moneter dengan tidak terbatas pada operasi pasar tebuka di pasar uang, baik Rupiah maupun valuta asing; dan

3) Menetapkan tingkat diskonto, menetapkan cadangan minimum, dan mengatur kredit atau pembiayaan.

b. Wewenang terkait dengan tugas mengatur dan menjaga kelancaran sistem pembayaran meliputi:

1) melaksanakan dan memberikan persetujuan dan izin atas penyelenggaraan jasa sistem pembayaran;

2) Mewajibkan penyelenggara jasa sistem pembayaran untuk menyampaikan laporan kegiatannya; dan

3) Menetapkan penggunaan alat/instrumen pembayaran.

\subsection{Pengertian Uang dan Perannya}

Uang dalam ilmu ekonomi tradisional didefinisikan sebagai setiap alat tukar yang 
dapat diterima secara umum. Alat tukar itu dapat berupa benda apapun yang dapat diterima oleh setiap orang di masyarakat dalam proses pertukaran barang dan jasa. Dalam ilmu ekonomi modern, uang didefinisikan sebagai sesuatu yang tersedia dan secara umum diterima sebagai alat pembayaran bagi pembelian barang-barang dan jasa-jasa serta kekayaan berharga lainnya serta untuk pembayaran hutang. Beberapa ahli juga menyebutkan fungsi uang sebagai alat penunda pembayaran.Secara kesimpulan, uang adalah suatu benda yang diterima secara umum oleh masyarakat untuk mengukur nilai, menukar, dan melakukan pembayaran atas pembelian barang dan jasa, dan pada waktu yang bersamaan bertindak sebagai alat penimbun kekayaan. $^{13}$

Keberadaan uang menyediakan alternatif transaksi yang lebih mudah daripada barter yang lebih kompleks, tidak efisien, dan kurang cocok digunakan dalam sistem ekonomi modern karena membutuhkan orang yang memiliki keinginan yang sama untuk melakukan pertukaran dan juga kesulitan dalam penentuan nilai. Efisiensi yang didapatkan dengan menggunakan uang pada akhirnya akan mendorong perdagangan dan pembagian tenaga kerja yang kemudian akan

\footnotetext{
${ }^{13}$ https://id.wikipedia.org/wiki/Uang
}

meningkatkan produktifitas dan kemakmuran.

Uang merupakan instrumen dari sebuah perekonomian. Tanpa uang, perekonomian akan berjalan dengan sangat lambat seperti yang terjadi pada masa barter. uang tidak lain adalah segala sesuatu yang dapat dipakai/diterima untuk melakukan pembayaran baik barang, jasa maupun utang. uang sebagai alat pengukur nilai, maka nilai suatau barang ataupun jasa dapat diperbandingkan. Contoh yang sederahana adalah, di Indonesia rupiah adalah alat yang sah secara konstitusional sebagai dasar pengukur nilai dari barang-barang maupun jasa diperdagangkan dipasar.Dengan demikian kita dengan mudah mengetahui nilai suatu barang. Bahkan dengan diketahuinya nilai suatu barang, maka dapat diketahui pula perbandingan nilai dengan barang yang lain.

Cikal bakal uang diawali dengan kegiatan tukar menukar barang atau disebut dengan istilah barter. Tetapi seiring dengan semakin banyaknya kebutuhan manusia, maka barter mulai mengalami kesulitan. Di antara faktor yang menyebabkan sulitnya barter, di antaranya adalah:

a. Kesulitan untuk menemukan orang yang memiliki barang yang dibutuhkan dan mau menukarkan barangnya.

b. Tidak adanya standar nilai untuk dipertukarkan. Dengan kesulitan tersebut 
di atas, akhirnya cara barter pun ditinggalkan dan manusia mulai mencari alternatif benda lain untuk dipergunakan dalam proses pertukaran. Setidaknya terdapat beberapa syarat agar sebuah benda dapat digunakan sebagai uang, yakni; ${ }^{14}$

1) Dapat diterima;

2) Setiap waktu dapat ditukar dengan barang apa saja;

3) Sulit mendapatkannya.

Benda-benda yang dijadikan sebagai alat pertukaran berupa kulit binatang, kerang dari laut dan benda-benda yang memiliki syarat di atas. Benda itu kemudian disebut uang barang. Uang barang tidak dapat terus dipergunakan sebagai alat pertukaran. Hal tersebut disebabkan karena ada kesulitan dalam ukuran, berat dan bentuk. Berdasarkan permasalahan tersebut, orang mulai mencari benda/logam yang memenuhi syarat-syarat sebagai berikut:

a. Tidak mudah rusak.

b. Diterima oleh umum.

c. Mudah disimpan dan mudah dibawabawa.

d. Harganya tinggi walaupun dalam jumlah yang kecil.

e. Sifatnya sama dan dapat saling mengganti.

f. Mudah dibagi tanpa mengurangi nilai. g. Harganya tetap dalam jangka waktu panjang.

Berdasarkan peryaratan diatas yang digunakan pada saat itu ialah logam sejenis Emas dan Perak. Uang logam menjadi istrumen pertama dalam sistem pembayaran pada saat itu dikerenakan beberapa kriteria kenap uang logam itu bisa menjadi sebagai media transaksi.

1. Fungsi Uang

Fungsi uang ada beberapa yang dibagi menjadi dua kategori, yaitu:

a. Fungsi Asli

1) Uang sebagai alat tukar

2) Uang sebagai alat hitung

b. Fungsi Turunan

1) Uang sebagai alat pembayaran yang sah

2) Uang sebagai penyimpan kekayaan atau pemindah kekayaan

3) Uang sebagai alat pendorong ekonomi

4) Uang sebagai alat pencicilan utang

Fungsi tersebut menjelaskan bahwa sesunggunya uang itu merupakan sesuatu yang sangat bermanfaat bagi masyarakat, memaksimalkan fungsi uang merupakan tugas dan tanggung jawab masyarakat.

2. Uang Sebagai Sistem Pembayaran

Salah satu tugas bank sentral sebagaimana khususnya Bank Indonesia sebagai Bank Sentral Republik Indonesia adalah mengatur dan menjaga kelancaran sistem pembayaran.

\footnotetext{
${ }^{14}$ Ibid., h.93
} 
Berdasarkan alat yang digunakan dalam sistem pembayaran, secara umum alat pembayaran dapat terbagi atas:

a. Alat pembayaran tunai, yaitu pembayaran yang menggunakan uang kartal/uang tunai yang meliputi Uang Kertas (UK) dan Uang Logam (UL).

b. Alat pembayaran nontunai, yaitu pembayaran yang menggunakan berbagai media atau instrumen selain uang tunai, seperti kartu kredit, ATM, kartu debet, dan uang elektronik.

\section{Uang Logam di Indonesia}

Mata uang pertama Indonesia adalah "Oeang Republik Indonesia" yang peredarannya bisa dibilang sangat singkat pada tahun 1946Pada masa pasca kemerdekaan sendiri, terdapat tiga mata uang yang beredar, yaitu mata uang Jepang, mata uang Hinda Belanda dan mata uang De Javasche Bank. Melalui Konferensi Meja Bundar (KMB) pada tahun 1949, dimana Indonesia diserahi kedaulatan mutlak atas negaranya, De Javasche Bank dinasionalisasikan menjadi Bank Indonesia pada tahun 1953 dan bertugas penuh meregulasi peredaran uang di Indonesia serta berfungsi sebagai kas umum dan kas pemerintah. $^{15}$

${ }^{15}$ Puji Antari Rahayu, Kajian Grafis Uang Logam Indonesia Periode Tahun 1951-2009, Wimba, Jurnal Komunikasi Visual \& Multimedia. Vol.2 No.1 Tahun 2010
Uang yang beredar di Indonesia ada dua macam, yaitu uang kertas dan uang logam yang dicetak oleh Perusahaan Umum Percetakan Uang Republik Indonesia (Perum PERURI) sejak tahun 1971.Uang kertas memiliki nominal yang lebih besar daripada uang logam.Karena memiliki nilai nominal yang besar, maka pada uang kertas terdapat unsur sekuritas untuk meminimalkan kasus pemalsuan uang yang sering terjadi. Unsur sekuritas tersebut meliputi benang pengaman, tanda air, cetak intaglio (teknik cetak dalam, sehingga hasil cetak tinta menjadi timbul) pada nominal uang yang tertera, recto verso (teks yang terpisah menjadi dua bagian dan diletakkan secara parallel di dua sisi), dan ada beberapa unsur sekuritas lain yang bisa diketahui jika ditempa sinar ultraviolet.

Pada masa perkembangannya uang di Indonesia sudah sangat berkembang dikarenakan Indonesia telah banyak mengeluarkan beberapa nominal uang baik itu uang logam maupun uang kertas, tapi kita akan lebih membahas perkembangan uang logam di Indonesia dan bagaiamana praktek penggunaannya. Uang di Indonesia memiliki beberapa nominal, uang yang paling kecil nominalnya yang pernah dikeluarkan pemerintah Indonesia yaitu, uang 1 Sen dan uang logam dengan nominal tertinggi yaitu, 1.000 Rupiah 


\section{METODOLOGI}

Pendekatan penelitian yang digunakan dalam penelitian ini adalah pendekatan kualitatif, digunakan pendekatan kualitatif dalam proposal ini karena penelitian ini bersifat mendeskripsikan Pranan Kantor Perwakilan Bank Indonesia Provinsi Sulawesi Tengah Dalam Upaya Meningkatkan Penggunaan uang Logam. Penelitian bersifat deskriptif menurut Suharsimi Arikunto lebih tepat apabila menggunakan pendekatan kualitatif. ${ }^{16}$

Dalam penelitian ini penulis mengambil tempat di Bank Indonesia Perwakilan Sulawesi Tengah yang beralamatkan di Jalan Dr. Samratulangi Nomor 23 Kota Palu. Sedangkan data dikumpul melalui cara observasi, wawancara mendalam, dan data dari berbagai dokumen yang ada.

Setelah berakhirnya pengumpulan data, maka data yang terkumpul tersebut kemudian dikelolah dalam sebuah proses untuk menumukan teori dari data. Pengelolahan data tersebut disebut analisis data. Menurut Moleong, analisis data adalah "Proses mengorganisasikan dan mengurutkan data kedalam pola, kategori dan satuan uraian dasar sehingga dapat ditemukan tema dan dapat dirumuskan

${ }^{16}$ Suharsimin Arikunto, Prosedur Penelitian Ilmiah, Suatu Pendekatan Praktek, (Edisi Kedua Cet, IX; Jakarta:Rineka Cipta, 1993, h.93 hipotesis kerja seperti yang disarankan oleh data". ${ }^{17}$

Penelitian ini adalah penelitian kualitatif, maka analisi itu berlangsung sejak pertama kali penulis ke lapangan sampai pengumpulan data tersebut menjawab semua permaslahan yang ada. Jadi, sejumlah fakta yang diperoleh dilapangan akan dikumpulkan dengan cara menuliskan atau mengadopsi, mengedit, mengklarifikasi, mereduksi dan kemudian dilanjutkan dengan penyajian.

\section{HASIL DAN PEMBAHASAN}

\subsection{Gambaran Lokasi Penelitian}

Kantor Perwakilan (Kpw) Bank Indonesia Provinsi Sulawesi Tengah diresmikan pada tanggal 8 September 1970 oleh Bapak Radius Prawiro, Gebernur Bank Indonesia pada saat itu. Kantor Perwakilan Bank Indonesia Sulawesi Tengah yang ke28. Awalnya kegiatan oprasional Kantor Perwakilan Bank Indonesia Sulawesi Tengah dilakukan di Kantor Perdagangan. Kantor Perwakilan Bank Indonesia Sulaesi Tengah ketika itu hanya terdiri dari Tiga seksi Yaitu Seksi Kas, Seksi Pembukuan, dan Seksi Umum dengan jumlah pegawai sebanyak 21 orang yang eberapa diantaranya merupakan pegawai detasiring dari Kantor Pusat Bank Indonesia. Adapun Bank Umum yang beroprasi pada saat itu yaitu Kantor Cabang

${ }^{17}$ Ibid., h. 20 
Bank BNI, Bank Bumi Daya, Bank Dagang Negara, dan Bank Rakyat Indonesia, serta Satu Bank milik pemerintah yaitu Bank Pembangunan Daerah Sulawesi Tengah (sekarang PT. Bank Sulteng).

Sementara itu, peresmian gedung Kantor Perwakilan Bank Indonesia Sulawesi Tengah saat ini (Jalan. Dr. Sam RatulangiNo.23 Palu) dilakukan tanggal 12 Februari 1972 oleh Direktur Bank Indonesia, Bapak M. Djoeana dibangun di atas tanah seluas $8.83 \mathrm{~m}^{2}$ yang merupakan tanah Hibah dari pemerintah daerah saat itu Gebernur Sulawesi Tngah Bapak M. Jasin dan Pimpinan Bank Indonesia Makassar Bapak Irlan Soehendra. Hinggah sat ini bangunan Kantor Perwakilan Sulawesi Tengah belum pernah mengalami perubahan bentuk yang berarti.

Bank Indonesia sebagai bank central yang Independen dalam melaksanakan tugas dan wewenangnya dimulai ketika sebuah undang-undang baru, yaitu Undang-Undang No.23 Tahun1999 Tentang Bank Indonesia dinyatakan berlaku pada tanggal 17 Mei Tahun 1999 dan sebagaimana telah diubah dengan Undang-Undang RI No. 6 Tahun 2009. Undang-Undang ini memberikan status dan kedudukan sebagai salah satu lembaga negara yang independen dalam melaksanakan tugas dan wwenangnya, bebas dari campur tangan pemerintah atau pihak lain, kecuali untuk hal-hal yang secara tegas diatur dalam Undang-Undang ini.

Saat ini untuk mewujudkan Visi dan Misi Kantor Perwakilan Bank Indonesia Sulawesi Tengah didukung 41 pegawai organik dan 21 orang pegawai non organik (PT. Binakarsa Swadaya) yang tersebar di 7 Fungsi unit yaitu Fungsi Asesmen dan Surveillance (FAES), Fungsi Data dan Statistik dan Ekonomi Keuangan (FDSEK), Fungsi Koordinasi dan Komunikasi Kebijakan (FKKK), Fungsi Pelaksanaan dan Pengembangan UMKN (FPPU), Unit Satuan Layanan Administrasi (USLA), Unit Oprasional Sistem Pembayaran, Pengawasan SP, PUR, KL, dan Unit Pengelolahan Uang Rupiah.

Dilihat dari sistem ketenagakerjaan Republik Indonesia, kedudukan Bank Indonesia sebagai lembaga Negara yang independen tidak sejajar dengan lembaga Negara lainnya seperti Dewan Perwakilan Rakyat, Badan Pemeriksaan Keuangan, dan Mahkamah Agung. Kedudukan Bank Indonesia yang khusus tersebut diperlukan agar Bank Indonesiadapat melaksanakan peran dan fungsinya sebagai otoritas moneter secara lebih efektif dan efesien. Meskipun Bank Indonesia berkedudukan sebagai lembaga Negara yang Independen, dalam melaksanakan tugasnya Bank Indonesia 
menjalin hubungan koordinasi dengan pemerintah dan pihak lainnya. ${ }^{18}$

\subsection{Fungsi Bang Indonesia}

Fungsi bank Indonesia antara lain menjalankan fungsi Komunikasi Koordinasi Kebijakan (FKKK) yang memiliki beberapa tugas pokok yang antara lain melaksanakan koordinasi dengan stakeholders dalam rangka pengendalian inflasi dalam wilayah kerja dan/atau antar wilayah kerja. Kemudian melakukan koordinasi dan program kerjasama dalam rangka pengembangan ekonomi daerah dan hubungan investor.

Kemudian Bank Indonesia juga berfungsi sebagi Unit Pengelolaan Uang bertugas untuk menghitung uang yang telah disetorkan oleh bank umum penhitungannya bisa dilakukan secara manual atau menggunakan mesin. Manual jika uang yang dihitung uang pecahan 20.000 kebawah. Tetapi jika uang 50.000 keatas sudah harus menggunakan mesin. Selain bertugas untuk menghitung uang, unit ini juga berfungsi sebagai penghacur uang yang sudah tidak layak edar, setiap harinya bank Indonesia akan menghancurkan uang yang sudah tidak layak edar, hal ini dilakukan agar uang tersebut tidak disalahgunakan oleh pihakpihak yang tidak bertanggung jawab.

\footnotetext{
${ }^{18}$ Arsip Kantor Perwakilan Bank Indonesia Provinsi Sulawesi Tengah
}

Selanjutnya Bank Indonesia menjalankan fungsi Analisi Sistem Pembayaran dan Pengelolaan Uang Rupiah Serta Keuangan Inklusif dan Perlindungan Kunsumen yang meliputi melakukan koordinasi/kerjasama dan/atau implementasi program KI dan memberikan layanan informasi dan mediasi perlindingan konsumen sistem pembayaran.

4.3 Upaya Kantor Perwakilan Bank
Indonesia Dalam Meningkatkan
Penggunaan Uanglogam

Kantor Perwakilan Bank Indonesia Provinsi Sulawesi $\quad$ Tengah selakuperpanjangan tangan kebijakan Bank Indonesia dalam melaksanakan tugas di bidangpengedaran uang, senantiasa berupaya untuk menjamin ketersediaan uangRupiah di seluruh wilayah kerja Kantor Perwakilan Bank Indonesia Sulawesi Tengah dalam jumlah nominal yang cukup dan pecahan yang sesuai serta dalam kondisi layak edar.

Pemenuhan uang Rupiah yang selama ini telah dilakukan Kantor Perwakilan Bank Indonesia Prov.Sulteng berupa:

a. Pelayanan Kas

Pelayanan kas oleh Kantor Perwakilan Bank Indonesia Prov. Sulteng secara umum terdiri dari penerimaan setoran dari bankbank, kegiatan penarikan, penukaran uang dan layanan kas lainnya. Tujuan dari layanan perkasan itu adalah untuk memenuhi 
kebutuhan masyarakat atas uang dan menjaga agar uang logam yang dianggap tidak berlaku atau tidak layak edar tetap dalam kondisi yang layak edar.

b. Penyetoran

$\quad$ Setoran adalah kegiatan bank
melakukan penyetoran uang ke
BankIndonesia.
c. Penukaran

Penyelenggaran penukaran uang dilakukan oleh Kantor Perwakilan Bank Indonesia Prov.Sulteng, baik secara langsung maupun tidak langsung. Terkait dengan kegiatan penukaran dan penggantian uang Kantor Perwakilan Bank Indonesia Prov Sulteng setiap hari Kamis dari Jam 09.00-11.30 WITA membuka loket untuk melayani masyarakat dalam hal, penukaran uang tidak layak edar (UTLE) dengan uang layak edar (ULE).

\section{d. Kas Keliling}

Kas keliling kepada masyarakat disebut kas keliling retail dilakukan di dalam kota dan/atau diluar kota, kas keliling kepada bank dan/atau pihak lain disebut kas keliling dilakukan di luar kota.

Kantor Perwakilan Bank Indonesia Provinsi Sulawesi Tengah selaku perpanjangan tangan kebijakan Bank Indonesia dalam pengedaran uang terus berupaya memenuhi kebutuhan uang kartal di masyarakat salah satunya uang logam.
"Kantor Perwakilan Bank Indonesia Provinsi Sulawesi Tengah berupaya meningkatkan penggunaan uang logam di masyarakat melalui Edukasi dan Sosialisasi. Dalam mengencarkan masyarakat untuk menggunakan uang logam Kantor Perwakilan Bank Indonesia melakukan kegiatan Gerakan Peduli Koin SulTeng, Jangan sia-siakan sekeping uang logam kamu dan dukung kelancaran transaksi pembayaran di masyarakat. Kegiatan peduli koin yang diselenggarakan Kantor Perwakilan Bank Indonesia Provinsi Sulawesi Tengah disebut dengan Gerakan Peduli Koin SulTeng. Gerakan Peduli Koin merupakan bagian dari Gerakan Peduli Koin Nasional yang sudah diselenggarakan oleh Kantor Pusat Bank Indonesia di Jakarta dan beberapa Kantor Perwakilan Dalam Negeri”. ${ }^{19}$

Usaha spesifik yang dilakukan oleh Kantor Bank Perwakilan Bank Indonesia Sulawesi Tengah yaitu hanya sekedar eduksi dan mendorng masyarkat agar menggunkan uang logam semaksimal mungkin guna memaksimalkan penggunaan uang logam di masyarakat.

Sosialisasi dan Edukasi yang dilakukan Bank Indonesia seperti Gerakan Peduli Koin SulTeng dan Cikur (Ciri-ciri Keaslian Uang Rupiah) mengklarifikasi kepada masyarakat bahwa uang logam yang beredar saat in masih berlaku, uang logam dianggap tidak berlaku kecuali dalam hal ini Bank Indonesia

${ }^{19}$ Remon Samora, Analis Fungsi Koordinasi, Komunikasi dan Kebijakan, Kantor Perwakilan Bank Indonesia Sulawesi Tengah, Wawancara Pribadi, Selasa 15 Agustus 2017 
dalam melaksanakan peran dan fungsinya dalam tahapan pengelolahan Uang rupiah sebagai berikut:

a. Perencanaan

b. Percetakan

c. Pengeluaran

d. Pengedaran

e. Pencabutan, penarikan dan pemusnahan

Uang adalah satuan nilai yang dijadikan sebagai alat transaksi dalam pembayaran di masyarakat, dimana pada uang tersebut tercantum nilai nominal, penerbit, serta ketentuan lainnya. Dalam Undang-Undang Nomor 7 Tahun 2011 tentang Mata Uang Pasal 1 Ayat (2) menyebutkan bahwa uang adalah alat pembayaran yang sah.

"Ada masa disaat hukum betul-betul haruscditegakkan dimana aturan yang mengenai penolakan uang logam diatur dalam Undang-Undang Nomor 7 Tahun 2011 Tentang Mata Uang"20

Pasal 33 Setiap orang dilarangmenolak utuk menerima uang rupiah yang penyerahannya dimaksudkan sebagai pembayaran atau untuk menyelesaikan kewajiban yang harus dipenuhi dengan rupiah dan atau untuk transaksi keuangan lainnya. Sanksinya pidana kurungan paling lama 1 (Tahun) dan pidana denda paling

\footnotetext{
${ }^{20}$ Kristoforus Ronald,Setingkat Asisten, Fungsi Koordinasi Komu ikasi dan kebijakan, Kantor Perwakilan Sulawei Tengah, Wawancara Pribadi, 20 Agustus 2017.
}

banyak Rp. 200.000.000.00 (Dua Ratus Juta rupiah.

\section{KESIMPULAN DAN SARAN}

Setelah penulis membahas serta menganalisis peranan Kantor Perwakilan Bank Indonesia Provinsi Sulawesi Tengah dalam upaya meningkatkan penggunaan uang logam, maka penulis dapat menarik kesimpulan antara lain:

1. Peranan Kantor Perwakilan Bank Indonesia Sulawesi Tengah dalam upaya meningkatkan penggunaan uang logam yaitu dengan melakukan sosialisasi dan edukasi mengenai uang logam melalui kegiatan sosialisasi kebanksentralan dan Gerakan Peduli Koin SulTeng, Soasialisi Cikur (Ciri-Ciri Keaslian Uang Rupiah).

2. Kendala dari segi waktu yaitu Kantor Perwakilan Bank Indonesia Provinsi Sulawesi Tengah tidak bisa mensosialisasikan uang logam keseluruh bagian masyarakat karena keterbatasan waktu dan tempat. Dikarenakan letak geografis dan sumber daya manusia (SDM).

Adapun solusi yang penulis berikan yaitu Kantor Perwakilan Bank Indoesia Provinsi Sulawesi Tengah harus berperan aktif dalam mengkaji ekonomi mikro. Terjadinya penolakan terhadap uang logam menandakan tidak adanya perhatian pelaku ekonomi mikro, padahal ekonomi mikro 
dapat menjaga kelancaran sistem pembayaran.

\section{DAFTAR PUSTAKA}

Adawiyah Rabiatul, "Peranan Kantor Perwakilan Bank Indonesia Kalimantan Selatan Dalam Upaya Meningkatkan Penggunaan Uang Logam" (Kalsel: Jurusan Perbankan Syariah, Skrpsi ini tidak diterbitkan 2017).

Arikunto

ProsedurPenelitianIlmiah,

SuatuPendekatanPraktek,

(EdisiKeduaCet,IX;

Jakarta:RinekaCipta, 1993, h.93)

Arsip Kantor Perwakilan Bank Indonesia Provinsi Sulawesi Tengah.

Atu Alfiandri Zainal, Fakultas Hukum Jurusan Ilmu Hukum, Peran Bank Indonesia

dalamMenganggulangiPeredaranUa

ngPalsu di Indonesia BerdasarkanPasal 244 dan 245 KUHP, Universitas Hasanuddin, Makassar, 2015.

Bank Indonesia, Buku Panduan Guru Ekonomi SMA/MA muatan kebanksentralan 2014., h.60.

Departemen Komunikasi Bank Indonesia, 25 Juni 2016http://bi.go.id.

http://id.m.wikipedia.org/wiki/bank_indonesi a diakses 24 Juli 2017.

https://id.wikipedia.org/wiki/Uang.

http://id.m.wikiedia.org/woki/uang diakses 1Agustus 2017.

https://kbbi.web/peranversionline.

http://uangindonesia.com/uang-logamindonesia-dari-masa-kemasa/.

http:///www.bi.go.iddiakses18Agustus2017.

Indrawati Sri Mulyani,. Teori Moneter, Lembaga penerbit Fakultas Ekonomi
Universitas Indonesia. Jakarta : 1988. h.4.

Kantor Bank Indonesia Provinsi Sulawesi Tengah,

KajianEkonomidanKeuangan

Regional ProvinsiAulawesi

Tengah.(Palu,2017).

Kamalia Rizki, Fakultas Syariah dan Ekonomi Islam Jurusan Perbankan Syariah, Peranan Kantor Perwakilan Bank Indonesia Provinsi Kalimantan Selatan dalamPemenuhanUangLayakEdar, Institut Agama Islam Negeri AntasariKalimantan Selatan, 2017.

MargonoS, PeenelitianPendidikan, (Cet,II; Jakarta :Rineka Putra Cipta, 2000), h.38.

MoleongLexi J, MetodelogiPenelitianKualitatif(Cet, XVII; $\quad$ Bandung: Remaja Rosdakarya,2002) h.3.

Nasution Mustafa Edwin, et al. eds. PengenalanEksklusifEkonomi Islam (Jakarta: Prenada Media Group, 2006), hlm. 239.

Nasution S., Metode Research PenelitianIlmiah, ( Cet. VII ; Jakarta : BumiAksara, 2004 ), h. 106.

Rahayu

PujiAntari, KajianGrafisUangLogam Indonesia PeriodeTahun 1951-2009, Wimba, Jurnal Komunikasi Visual \& Multimedia. Vol.2 No.1 Tahun 2010.

Rivai Veithzal, Bank and Finncial Institution Management, PT.RajaGrafindo Persada, Jakarta 2007. h.31.

RuslanRosady, MetodePenelitian-Publik Relations danKomunikasi, (Jakarta: PT Raja GrafindoPersada, 2006), 211.

Soekanto Soejono, Sosiologi Suatu Pengantar , PT. Raja Grafindo Persada, Jakarta Januari 2012. hal.212. 
Tim Alumni,. Koleksi Mata Uang Berbagai

Negara., penerbit alumni 1985

bandung. Bandung:1985. h. 5,6. 